Reprod. Nutr. Dévelop., 1986, 26 (3), 801-814.

\title{
Effects of valerate and isobutyrate on fatty acid secretion by the isolated perfused mammary gland of the lactating goat
}

\author{
Anne-Marie MASSART-LEËN, G. PEETERS, Georgette VANDEPUTTE-VAN \\ MESSOM, E. ROETS, C. BURVENICH
}

Department of Physiology,

Veterinary Faculty of the University of Ghent

Casinoplein 24, B-9000 GENT, Belgium.

\begin{abstract}
Summary. The isolated mammary glands of six lactating goats were perfused with heparinized and oxygenated blood for 8 to $11 \mathrm{~h}$. Adequate quantities of glucose, acetate and amino acids (including valine) were added to the perfusate. Either unlabelled valerate or unlabelled isobutyrate was added in excess to the perfusate of one gland, while the respective symmetrical gland was used as a control.

After the administration of valerate, the proportions of the odd-numbered fatty acids $\left(C_{11: 0}, C_{13: 0}, C_{15: 0}\right)$ in the milk fat, collected every hour during perfusion, rose progressively after $5 \mathrm{~h}$ until the end. The synthesis of milk fatty acids from valerate is discussed.

After isobutyrate was added to the perfusate, iso $C_{12: 0}$, iso $C_{14: 0}$ and iso $C_{16: 0}$ in the milk fat increased as compared to the control. The effect of isobutyrate indicated that valine acted as a precursor of milk iso-branched fatty acids after its metabolisation to isobutyryl-CoA.

During perfusion in the presence of the complete substrate mixture, the proportion of certain major milk fatty acids $\left(C_{10: 0}, C_{12: 0}, C_{14: 0}\right.$ and $\left.C_{16: 0}\right)$ increased, whereas the proportion of $\mathrm{C}_{18: 0}$ and $\mathrm{C}_{18: 1}$ decreased. These effects have been ascribed to the presence of acetate and $\beta$-hydroxybutrate in the substrate mixture.
\end{abstract}

\section{Introduction.}

Besides even-numbered straight-chain fatty acids, odd-numbered and branched-chain (e.g. monomethyl-substituted (1), iso (2) and anteiso ( ${ }^{3}$ ) fatty acids are also present in goat milk fat (Massart-Leën et al., 1981).

(1) The methyl-branches appear only on the even-numbered C-atoms, the C-atom of the carboxyl group being counted as 1 .

$\left.{ }^{2}\right)$ Contains a terminal isopropyl group $\left(\mathrm{CH}_{3}-\stackrel{\text { C }}{\mathrm{C}} \mathrm{H}-\left(\mathrm{CH}_{2}\right)_{n}-\mathrm{COOH}\right.$.

(3) Contains a methyl group on the antepenultimate carbon atom $\left(\mathrm{CH}_{3}-\mathrm{CH}_{2}-\stackrel{\mathrm{C}_{3}}{\mathrm{C}}-\left(\mathrm{CH}_{2}\right)_{n}-\mathrm{COOH}\right.$.

Reproduction, Nutrition, Développement, $n^{\circ}$ 3-1986. - 4 
Several studies have been made on the ability of the mammary gland to utilize volatile fatty acids as precursors in the synthesis of odd-numbered and branched-chain fatty acids. James et al. (1956) showed that propionate acts as a precursor in the synthesis of odd-numbered fatty acids in the perfused lactating cow udder. This work was later confirmed and extended in our laboratory using the isolated lactating goat udder (Massart-Leën et al., 1983). Adding propionate to the perfusion blood resulted in an increase of the proportions of odd-numbered and monomethyl-substituted fatty acids present in milk fat, while there was no difference in the iso or anteiso series. Gerson et al. (1960) injected $\left[1-{ }^{14} \mathrm{C}\right]$ valeric acid into the jugular vein of the cow and concluded that there was a breakdown of this substrate into $\mathrm{C}_{2}$ and $\mathrm{C}_{3}$ components. Although valeric acid acts as a precursor in the synthesis of saturated straight-chain odd-numbered fatty acids of milk fat, it is not a direct precursor.

Little is known about lactating mammary gland synthesis of iso and anteiso acids of milk fat. No direct incorporation of isovalerate into the branched-chain acids by perfused cow's udder has been demonstrated. On the other hand, there is evidence that isovalerate is broken down into $C_{2}$ and $C_{3}$ units by the gland (Verbeke et al., 1959). In perfusion experiments on isolated lactating goat mammary glands carried out in the presence of $\left[\mathrm{U}-{ }^{14} \mathrm{C} ; 2,3-{ }^{3} \mathrm{H}\right]$-valine, the radioactivity of total milk fat was very low and most of it was localized in iso $C_{16: 0}$ and iso $C_{14: 0}$ fatty acids with smaller amounts in iso $C_{15: 0}$ (Roets et al., 1979). These results suggested that isobutyryl-CoA acts as a primer molecule in the synthesis of iso acids with an even number of carbon atoms. Isobutyryl-CoA is a normal metabolite of valine catabolism.

The purpose of the present work was to investigate whether valeric acid and isobutyric acid can act as precursors in the synthesis of milk odd-numbered and branched-chain fatty acids by perfused lactating goat mammary gland. Our technique was based on the fact that a rise in the proportion of certain fatty acids in the secreted milk fat, as compared to the control gland, may occur when unlabelled precursor is added to the perfusion blood.

\section{Material and methods}

A. Mammary gland perfusion. - The goats received hay ad libitum and concentrates at $1 \mathrm{~kg} /$ day. They were milked twice daily. Twelve mammary glands from six of these goats yielding 18 to $45 \mathrm{ml}$ of milk per hour per gland were perfused at constant pressure for 8 to $11 \mathrm{~h}$. In total, 6 perfusion experiments were performed. In each experiment both symmetric glands from the same animal were perfused separately. When a perfusion experiment was to be on day 3, milk samples were collected from the left and right glands of the live animals on day 1 at $3: 30$ p.m. (preperfusion sample a), on day 2 at 8 a.m. (preperfusion sample b) and $3: 30$ p.m. (preperfusion sample c) and on day 3 at $8 \mathrm{a} . \mathrm{m}$. (preperfusion sample d). On day 2 at midday, the food was removed and fasting began. On the morning of day 3 , the two glands were emptied by milking. They were then 
separated and excised under general and lumbosacral anesthesia. A modified form of the perfusion technique of Hardwick and Linzell (1960) and Hardwick et al. (1961) was used. The perfusion circuit for each gland included artificial lung, heart and kidney systems and a blood reservoir. In the artificial kidney, blood was circulated through 11 meters of dialysis tubing immersed in 20 liters of Krebs solution containing glucose, acetate, amino acids and antibiotics (Roets et al., 1974). The perfusion fluid consisted of 1.3 liters of heparinized homologous blood to which $1.3 \mathrm{mg}$ of cyproheptadine (Merck, Sharp \& Dohme) were added in order to block the vasoconstriction induced by 5-hydroxytryptamine released from blood platelets. The isolated gland was milked at the onset of perfusion (milk sample 0 ) and at 1-hour intervals by a teflon teat cannula after intra-arterial injection of $50 \mathrm{mU}$ of oxytocin. During perfusion, a substrate solution containing plasma proteins, glucose, acetate and amino acids, prepared according to Hardwick and Linzell (1960), was infused by a peristaltic pump. This mixture was calculated so that $1 \mathrm{ml}$ of solution provided all the precursors for the formation of $0.5 \mathrm{ml}$ of goat's milk. This solution was run into the perfusate continuously at a rate determined hourly by the milk yield of the previous hour (Hardwick et al., 1961). The total volume of milk produced during perfusion amounted to 57 to $124.5 \mathrm{ml} /$ gland. Two glands were perfused with sodium valerate while the two symmetrical glands were used as controls. Four glands were perfused with sodium isobutyrate, the four symmetrical halves acting as controls. Sodium valerate $(1.5 \mathrm{~g})$ or sodium isobutyrate $(1.5 \mathrm{~g})$ was added to $250 \mathrm{ml}$ of the substrate solution. As milk yield varied in the different experiments and at different times, the volumes of substrate solution, and consequently the quantity of valerate or isobutyrate added to the perfusate and the infusion rate, also varied (table 1). As the 20 liters of kidney fluid were in equilibrium with the blood, $0.5 \mathrm{~g}$ of valerate or isobutyrate was added to this fluid in the respective experiments. The amounts of valerate or isobutyrate added to the perfusate and the kidney fluid, respectively, resulted in a proportion which was similar to that of the acetate added to these liquids, as described by Hardwick and Linzell (1960). It should be noted that all the perfused glands received valine via the kidney fluid and the substrate solution. However, they did not receive propionate. Further experimental details related to these perfusions are given in table 1.

B. Analytical methods. - The milk components (lactose, triacylglycerols, casein and citric acid) were quantitatively analysed as described previously (Massart-Leën et al., 1970). Triacylglycerols from milk fat were transmethylated, and the resulting methylesters from $C_{10: 0}$ to $C_{20: 0}$ were quantitatively (percentage of total fatty acid weight) analysed by capillary gas chromatography. Methylesters below $\mathrm{C}_{10: 0}$ were not quantified due to gas chromatograph limitations. Further details on the analytical procedure have been described by Massart-leën et al. (1983) and Massart-Leën and Peeters (1985). The carbon number values of the eluting branched-chain fatty acids were compared with those obtained previously by reference standards using $\mathrm{GC} /$ mass spectrometry under similar chromatographic conditions (Massart-Leën et al., 1981). 


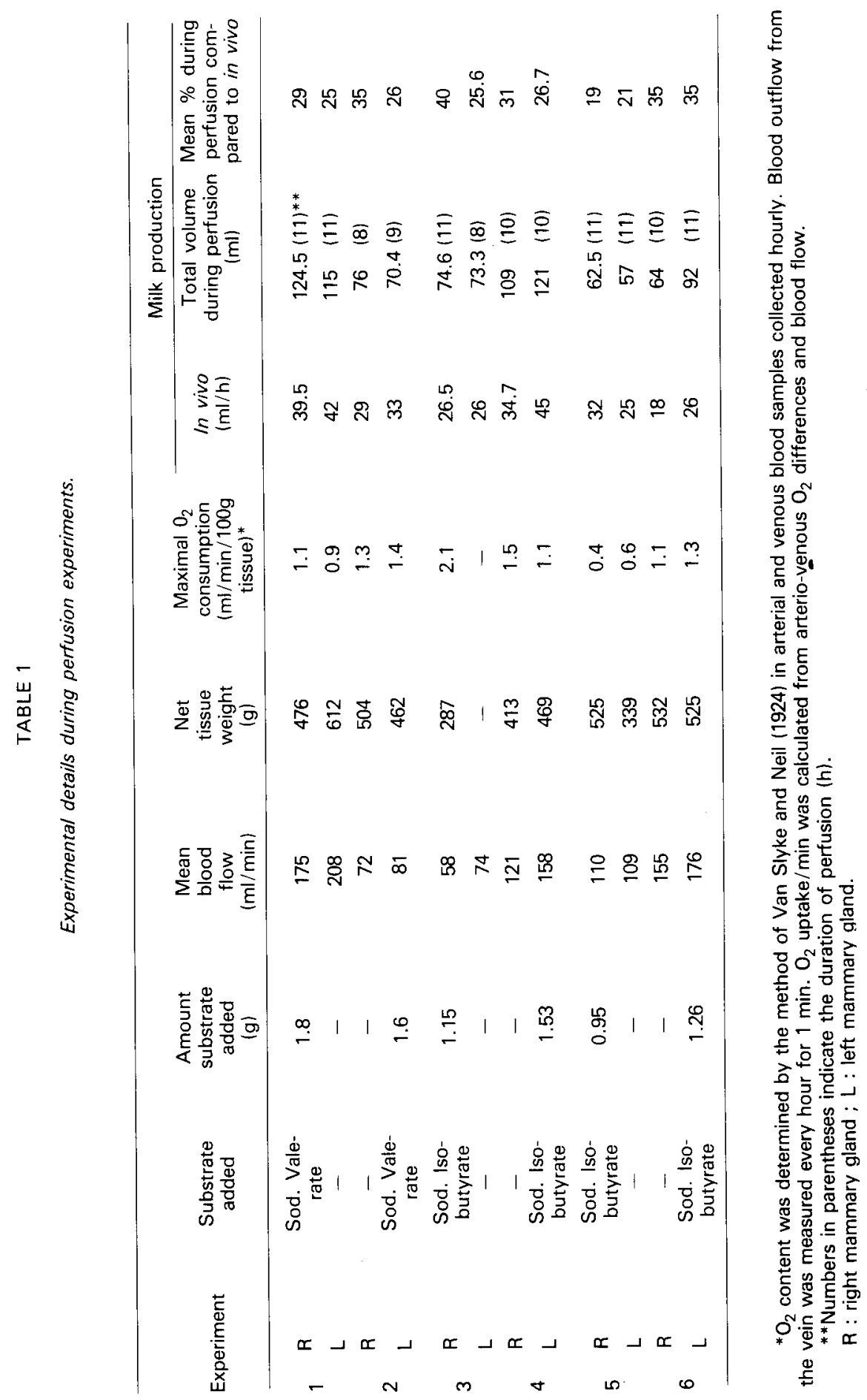




\section{Results}

Figure 1 shows a typical graph of milk production during perfusion experiment 1 (table 1). The milk obtained during perfusion had about the same composition as that collected in vivo. In common with other perfusion experiments, the lactose content was higher than in vivo. Citic acid and casein tended to increase towards the end of the experiment. The triacylglycerol concentrations of milk collected during perfusion did not differ between the control glands and their respective symmetric glands receiving valerate or isobutyrate. As all donor goats were fasted for $20 \mathrm{~h}$ prior to surgery, the proportions of several acids either declined or increased in milk fat (figs. 2, 3, 4). The low concentrations at the onset of perfusion were favourable for demonstrating the activating effects of either valerate or isobutyrate administration on the synthesis of fatty acids during perfusion.

Valerate perfusion. - Figure 2 shows the mean concentrations and ranges of milk odd-numbered fatty acids $\left(C_{11: 0}, C_{13: 0}, C_{15: 0}, C_{17: 0}\right)$ of valerate experiments 1 and 2 (table 1) as compared with their control symmetric experiments. The preperfusion percentages of these fatty acids are also shown (milk samples a, b, c, d, 0 ; see Material and methods). The percentages of $\mathrm{C}_{11: 0}, \mathrm{C}_{13: 0}, \mathrm{C}_{15: 0}$ declined and $\mathrm{C}_{17: 0}$ in samples $\mathrm{d}$ and 0 (after 20 and $24 \mathrm{~h}$ of fasting) rose as compared with the respective values in samples $a, b, c$ (normal milk).

During perfusion in the presence of valerate, the odd-numbered fatty acids $\left(C_{11: 0}, C_{13: 0}\right.$ and $\left.C_{15: 0}\right)$ of the milk fat rose gradually and significantly from the 5 th hour of perfusion until the end (fig. 2). The proportions of these acids in the control experiments decreased slightly towards the end of perfusion as compared to preperfusion levels. The proportions of $\mathrm{C}_{17: 0}$ during perfusion were nearly equal in the glands receiving valerate and in the control glands.

No difference between the valerate and control glands was observed as to proportions of even-numbered straight-chain saturated $\left(C_{10: 0}, C_{20: 0}\right)$, unsatura-
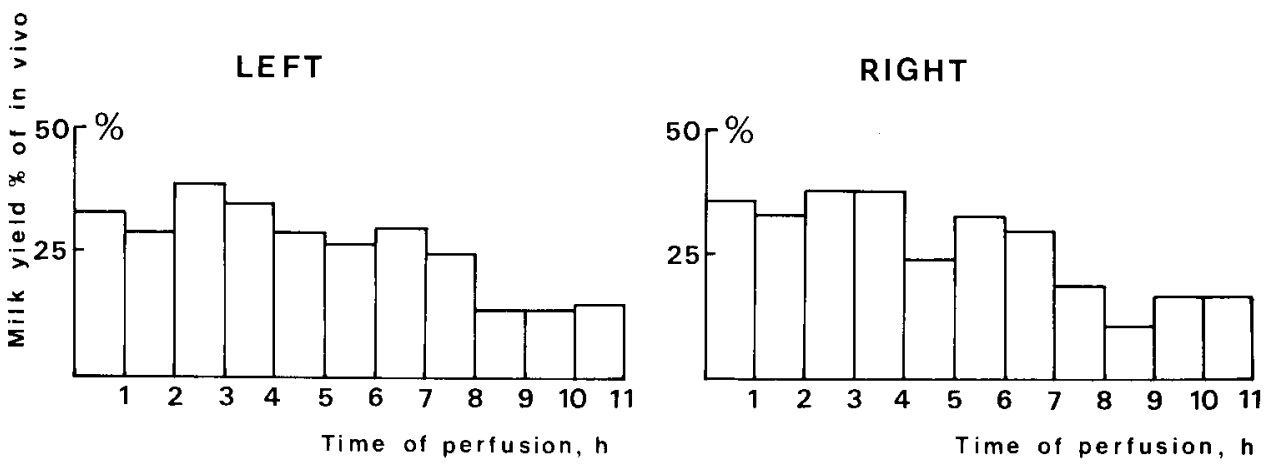

FIG. 1. - Hourly milk yield (percentage of hourly in vivo production) during perfusion of symmetric glands of the same animal (experiment 1, table 1). Valerate was added to the perfusate of the right gland; the left gland was used as a control. 
ted $\left(\mathrm{C}_{14: 1}, \mathrm{C}_{16: 1}, \mathrm{C}_{17: 1}, \mathrm{C}_{18: 1}, \mathrm{C}_{18: 2}\right)$ and branched-chain (iso, anteiso and monomethyl-substitued) fatty acids (data not shown).

In the preperfusion milk samples derived from animals in vivo after 20 and

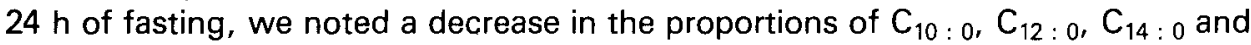
$\mathrm{C}_{16: 0}$, while the proportions of $\mathrm{C}_{18: 0}$ and $\mathrm{C}_{18: 1}$ rose. During perfusion, the proportions of $C_{10: 0}, C_{12: 0}, C_{14: 0}$ and $C_{16: 0}$ rose again, while $C_{18: 0}$ and $C_{18: 1}$ decreased. Similar changes in the proportions of the major fatty acids of milk fat were found in the isobutyrate experiments before and during perfusion. These results are shown in figure 4.

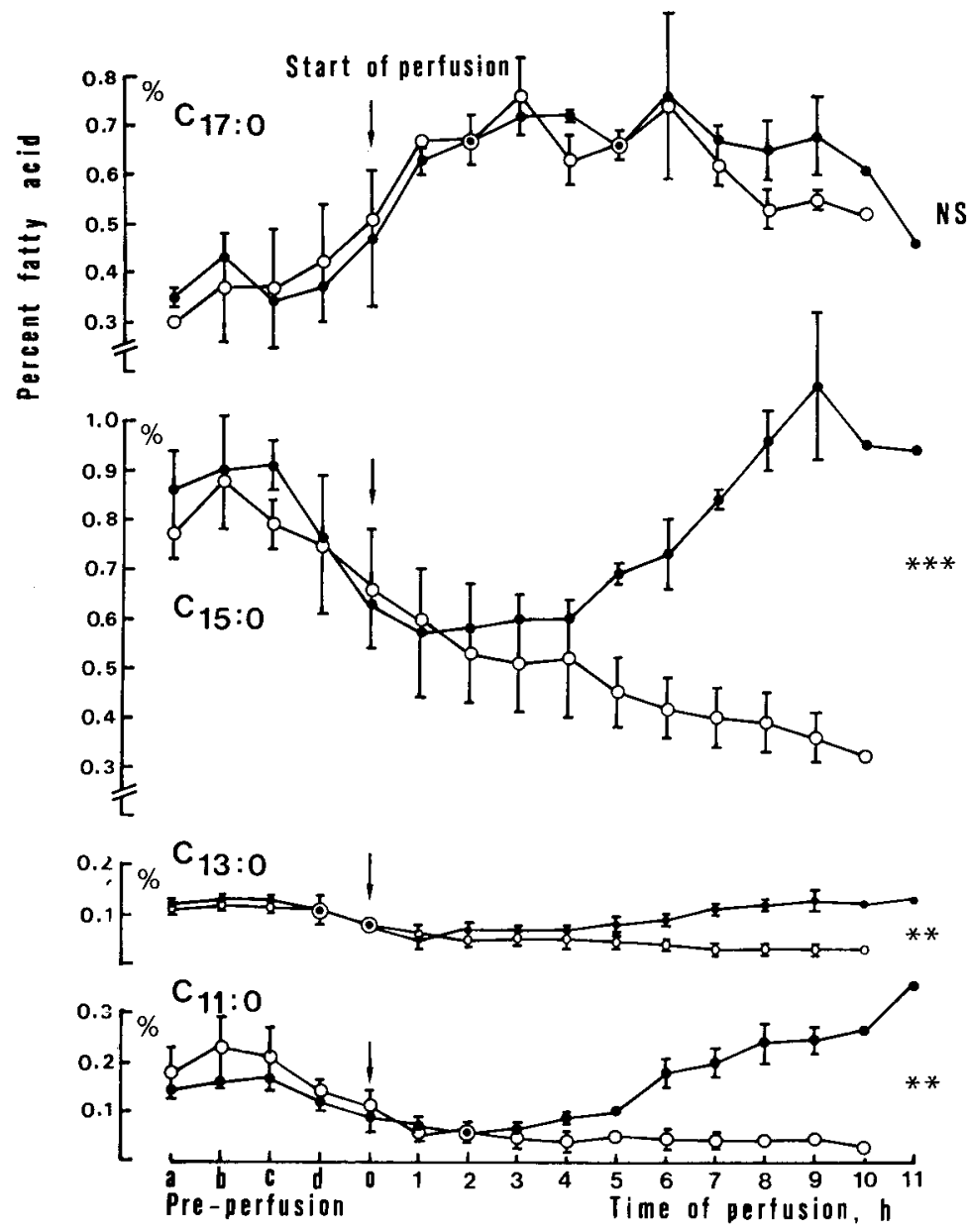

FIG. 2. - Effect of valerate administration (mean values and ranges of expts 1 and 2) on the concen-

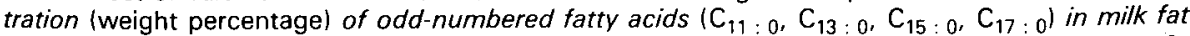
during perfusion of goat mammary glands. -_—, valerate-infused glands; $0 \_-0$, control glands. a, b, c, d, 0 : pre-perfusion samples (see Materials and methods). Significances were calculated by the paired t-test to compare the fatty acid proportions of the control and valerate glands from the beginning of the perfusion until the end ${ }^{* *} P<0.01 ;{ }^{* *} P<0.001$; NS : not significant). 
Isobutyrate perfusion. - Figure 3 shows the concentrations of branchedchain fatty acids with iso configuration and an even number of total $\mathrm{C}$-atoms in the chain in the four isobutyrate experiments as compared with the controls. The percentages in milk fat samples before perfusion are also given (samples $a, b, c$, $\mathrm{d}, 0$ ). The proportions of iso $\mathrm{C}_{18: 0}$ acid (carbon number: 17.52) tended to increase in samples $d$ and 0 (collected after 20 and $24 \mathrm{~h}$, respectively, of fasting), whereas shorter chain acids, i.e. iso $\mathrm{C}_{12: 0}$ (carbon number : 11.55), iso $\mathrm{C}_{14: 0}$ (carbon number : 13.55) and iso $\mathrm{C}_{16: 0}$ (carbon number : 15.55), decreased.

During perfusion there was a distinct and significant increase of iso branched-chain fatty acids : iso $\mathrm{C}_{12: 0}$ (carbon number: 11.55), iso $\mathrm{C}_{14: 0}$ (carbon number : 13.55 ) and iso $\mathrm{C}_{16: 0}$ (carbon number : 15.55) in glands receiving isobutyrate as compared with control glands. However, the proportions of iso $\mathrm{C}_{18: 0}$ (carbon number : 17.52) in control and isobutyrate glands were very similar. No increase was observed in isobutyrate glands for the iso fatty acids with an odd number of total $C$-atoms in the chain. Unsaturated $\left(C_{14: 1}, C_{16: 1}, C_{17: 1}, C_{18: 1}\right.$, $\left.\mathrm{C}_{18: 2}\right)$, odd-numbered $\left(\mathrm{C}_{11: 0}-\mathrm{C}_{17: 0}\right)$ and monomethyl-substituted branched-chain
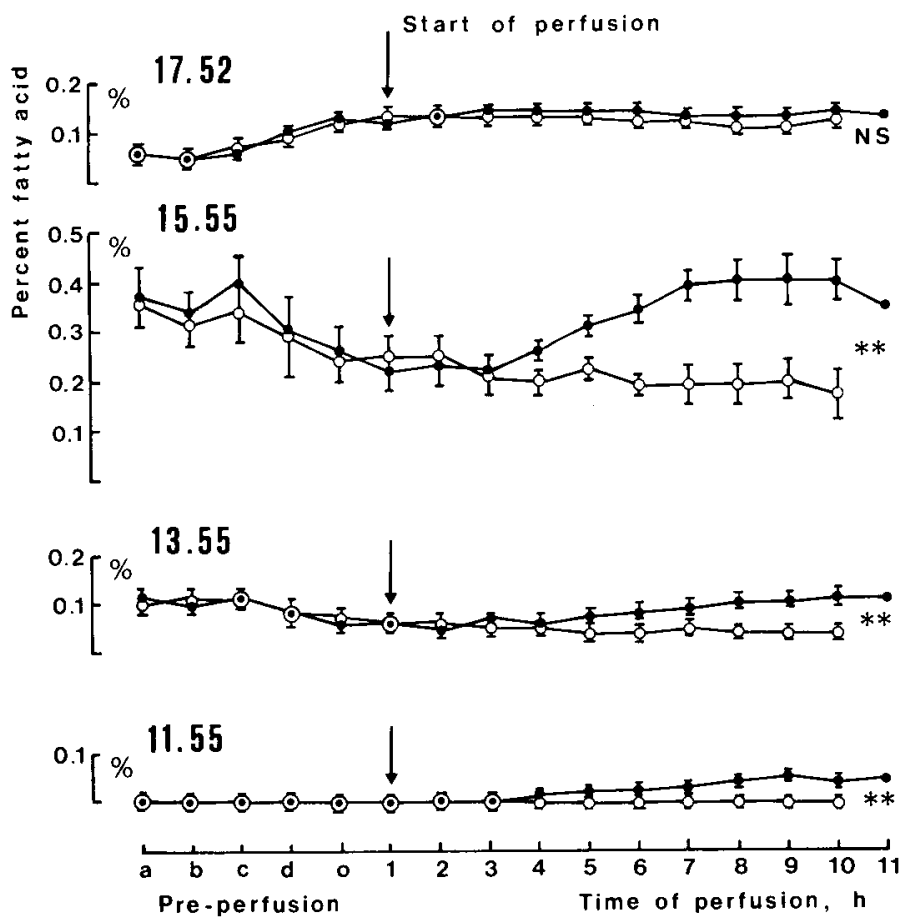

FIG. 3. - Effect of isobutyrate administration (expts $3,4,5,6$; table 1) on the concentration (weight percentage) of iso-fatty acids in milk fat during perfusion of goat mammary glands : carbon numbers : 11.55 (isododecanoate), 13.55 (isotetradecanoate), 15.55 (isohexadecanoate) and 17.52 (isooctadecanoate). Means \pm S.E. $-\longrightarrow \longrightarrow$, isobutyrate-infused glands; $0 \longrightarrow$, control glands. a, b, c, d, 0 : pre-perfusion samples (see Materials and methods). The significance of differences between means was calculated by the paired t-test to compare the fatty acid proportions of the control and the isobutyrate glands from the beginning of the perfusion until the end ${ }^{* * P}<0.01 ;$ NS : not significant). 
fatty acids showed no difference between control and isobutyrate glands either (data not shown). Changes in the concentrations of major milk fatty acids $\left\{C_{10: 0}\right.$.

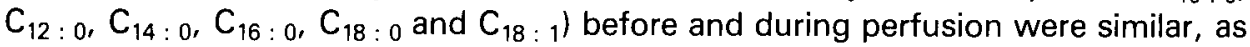
described for the valerate experiments (fig. 4).

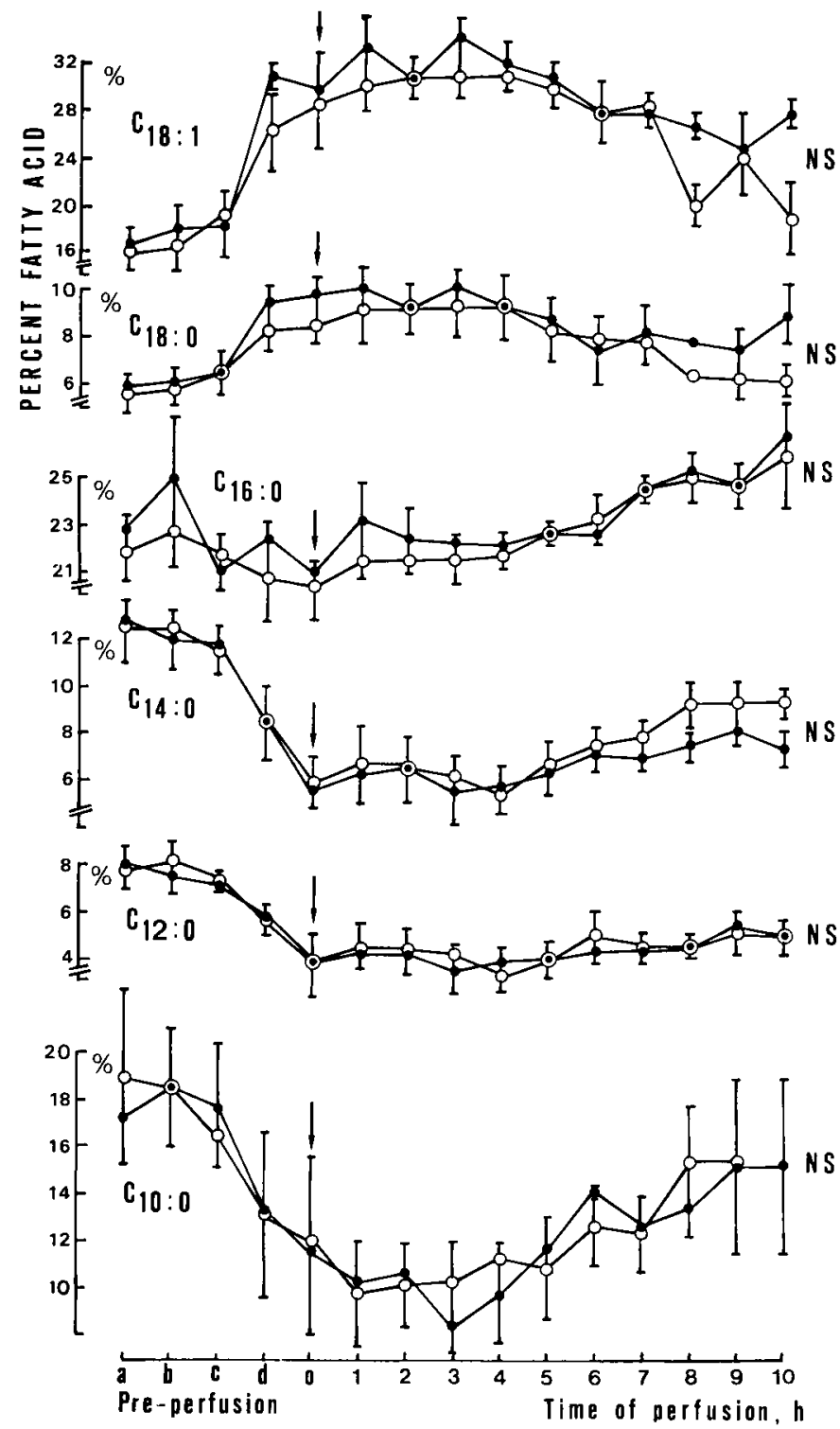

FIG. 4. - A comparison of the concentration (weight percentage) of major fatty acids $\left(\mathrm{C}_{10: 0}\right.$. $\mathrm{C}_{12: 0,} \mathrm{C}_{14: 0}, \mathrm{C}_{16: 0}, \mathrm{C}_{18: 0}, \mathrm{C}_{18: 1}$ ) in milk fat, during perfusion of goat mammary glands in the presence of isobutyrate lexpts $3,4,5,6$ of table 1 ), with that of the contro/s. Means \pm S.E. : - — : isobutyrate-infused glands; $0 \_0$ : control glands. a, b, c, d, 0 : preperfusion samples (see Materials and methods). The significance of differences between means for the paired data during perfusion is indicated (NS : not significant). 
Table 2 shows the correlations between the mean concentrations obtained during perfusion (samples 0 to 10 ) of the odd-numbered $\left(C_{11: 0}, C_{13: 0}, C_{15: 0}\right.$, $\left.C_{17: 0}\right)$, major milk $\left(C_{10: 0}, C_{12: 0}, C_{14: 0}, C_{16: 0}, C_{18: 0}\right.$ and $\left.C_{18: 1}\right)$ and iso-branched (carbon numbers : 13.54, 15.54 and 17.52) fatty acids from the four glands perfused with isobutyrate.

\section{Discussion.}

In perfusion experiments on lactating goat mammary glands, in which propionate was added to the perfusate (Massart-Leën et al., 1983), a significant increase was observed in the odd-numbered fatty acids $\left(C_{11: 0}, C_{13: 0}\right.$ and $\left.C_{15: 0}\right)$ as well as in the monomethyl-substituted branched fatty acids of milk fat. It may be assumed that propionate was metabolized to methylmalonyl-CoA before its incorporation into the monomethyl-substituted fatty acids. Similar results were obtained in the present experiments after adding valerate, with the exception of monomethyl-substituted branched-chain fatty acids. The concentrations of $C_{17: 0}$ in milk fat remained nearly constant.

After intravenous injection of $\left[1-{ }^{14} \mathrm{C}\right]$-valeric acid into the jugular vein of the lactating cow, Gerson et al. (1960) concluded that valeric acid did not act as a direct precursor in the formation of odd-numbered fatty acids since even and oddnumbered fatty acids of similar molecular weight had practically similar specific radioactivity. The breakdown of valeric acid to a $C_{2}$ and $C_{3}$ unit was suggested.

When mammary gland slices of lactating mice were incubated with $\left[1-{ }^{14} \mathrm{C}\right]$ valerate and unlabelled glucose, radioactivity was found in the even and oddnumbered fatty acids (Rao and Abraham, 1975). $\beta$-Oxidation of $\left[1-{ }^{14} \mathrm{C}\right]$-valerate yielded $\left[1-{ }^{14} \mathrm{C}\right]$-acetyl-CoA and unlabelled propionyl-CoA, and hence the substrates for both the even and odd-chain labelled fatty acids were available. There was no indication of direct esterification of valerate by the mammary gland. When [1${ }^{14} \mathrm{C}$ ]-heptanoate and unlabelled glucose were used as substrates, a large percentage of the total ${ }^{14} \mathrm{C}$ activity in the fatty acids was still present as heptanoate and represented direct esterification by the gland.

In the present experiments, adding an excess of unlabelled valerate to the perfusate only caused an increase in the proportion of odd-numbered fatty acids. We concluded that valerate, like propionate, acts as a precursor in the synthesis of odd-numbered fatty acids $\left(C_{11: 0}, C_{13: 0}, C_{15: 0}\right)$ in goat milk fat. No increase of either straight-chain even-numbered or monomethyl-substituted branched fatty acids was observed. Both of them could eventually be synthesized if valerate was broken down to $\mathrm{C}_{2}$ and $\mathrm{C}_{3}$ components. Our results apparently indicate the direct incorporation of valerate into odd-numbered fatty acids, i.e. an elongation giving rise to odd-numbered fatty acids with longer chains. However, this conclusion has to be viewed with caution. As all the glands received adequate quantities of acetate during perfusion, this substrate might have interfered with the putative effect of valerate on the synthesis of straight-chain even-numbered fatty acids. It is possible that the concentration of the $C_{3}$ component derived from valerate breakdown was too small to cause an appreciable increase of monomethyl- 


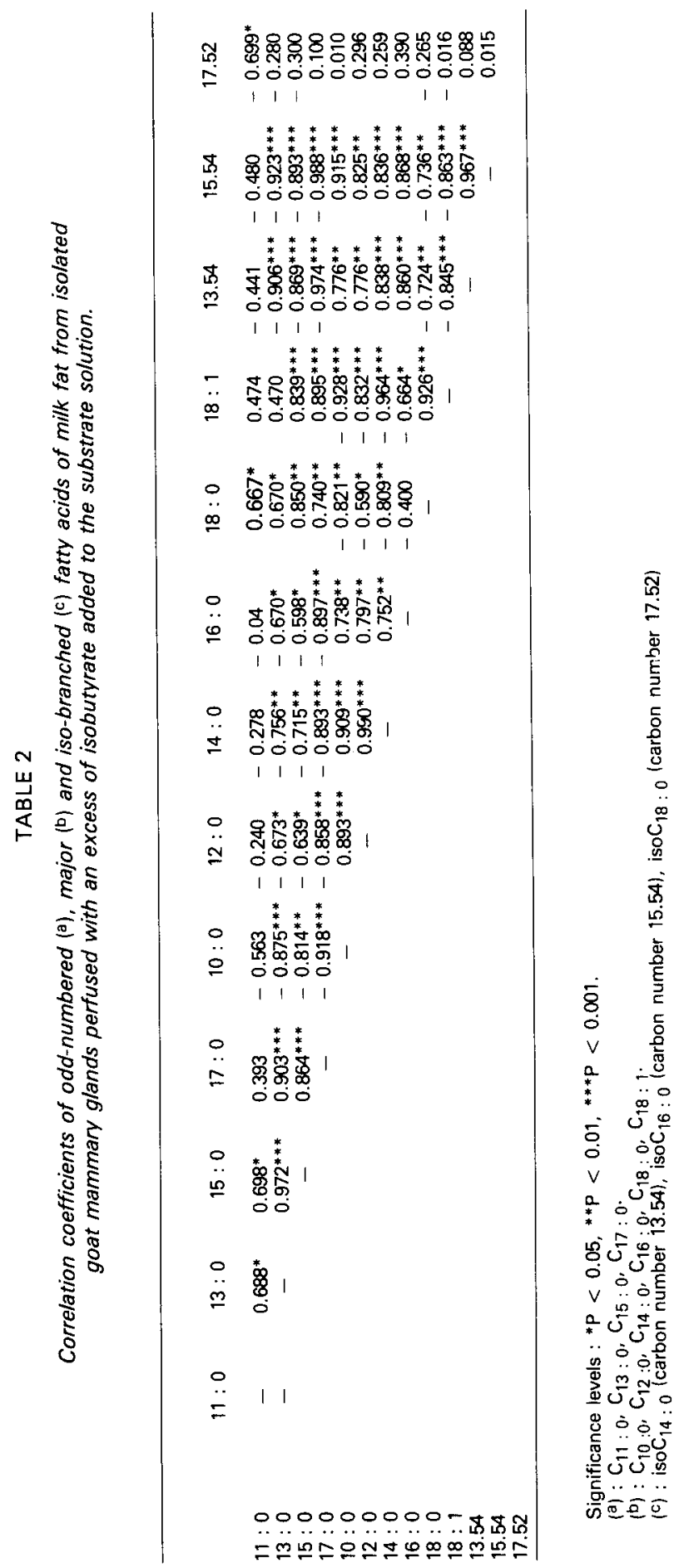


substituted fatty acids after unlabelled valerate was added to the perfusate. In our earlier propionate perfusion experiments (Massart-Leën et al., 1983), in which an increase in the proportions of monomethyl-substituted branched fatty acids was observed, a large quantity of propionate, much higher than the physiological level, was added to the perfusate. ${ }^{14} \mathrm{C}$ experiments are needed in order to study the possible breakdown of valerate. In view of the presence of valerate in the artificial blood of lactating goats, it is likely that valerate contributes to the synthesis of milk odd-numbered fatty acids $\left(C_{11: 0}, C_{13: 0}, C_{15: 0}\right)$ by the lactating goat mammary gland in vivo. However, its quantitative contribution must be minor since the blood concentration of valerate has been evaluated as only $\pm 5 \mu \mathrm{Eq} / 100 \mathrm{ml}$ of blood (Ramsey and Davis, 1965).

In earlier experiments in which $\left[\mathrm{U}-{ }^{14} \mathrm{C} ; 2,3-{ }^{3} \mathrm{H}\right]-\mathrm{L}$-valine was added to the perfusate of the isolated mammary gland (Roets et al., 1979), the highest specific activity was found in isohexadecanoate (iso $\mathrm{C}_{16: 0}$ ), followed by isotetradecanoate (iso $C_{14: 0}$ ). The specific activities of $C_{15: 0}$ reached only one-fourth of the specific activities of the iso acids. In the present experiments, we observed a two-fold, significant increase of isotetradecanoate (iso $\mathrm{C}_{14: 0}$ ), isohexadecanoate (iso $\mathrm{C}_{16: 0}$ ) and isododecanoate (iso $\mathrm{C}_{12: 0}$ ) after isobutyrate was added to the perfusate. This is in line with our earlier findings. We may assume that isobutyryl-CoA acts as a primer molecule in the formation of iso acids with an even number of $\mathrm{C}$-atoms in the chain.
$\mathrm{CH}_{3}>\mathrm{CH}-\mathrm{COSCoA}$
$+\mathrm{HOOC}$
Isobutyryl-CoA
malonyl-CoA
$\mathrm{CH}_{3}>\mathrm{CH}-\mathrm{CH}_{2}-\mathrm{CH}_{2}-\mathrm{COSCoA}$
iso acid with even
number of $\mathrm{C}$-atoms

Incubation studies of a purified fatty acid synthesizing system in rat adipose tissue (Horning et al., 1961), with isobutyryl-CoA as a primer, resulted in the formation of iso $C_{14: 0}$, iso $C_{16: 0}$ and iso $C_{18: 0}$ acids. The synthesis of iso $C_{14: 0}$ and iso $C_{16: 0}$ in adipose tissue is in accordance with results obtained in the present study on isolated mammary gland. We did not detect any synthesis of iso $C_{18: 0}$. This is quite understandable as the lactating mammary gland of ruminants synthesizes very little $C_{18}$ fatty acid in contrast to the adipose tissue.

Isobutyryl-CoA is a normal metabolite of valine catabolism. In earlier experiments (Roets et al., 1979), we concluded that about $30 \%$ of the valine molecules taken up by the mammary gland were oxidized to $\mathrm{CO}_{2}$, indicating that valine is extensively oxidized by the gland. In the perfusate of glands perfused with $\left[\mathrm{U}-{ }^{14} \mathrm{C} ; 2,{ }^{3}{ }^{3} \mathrm{H}\right]$-L-valine, the specific activity of isobutyrate was of the same order as that of valine. Valine was incorporated into isobutyrate by lactating mammary gland slices (Derrig et al., 1973). The rise of three iso fatty acids in the present study after the administration of unlabelled isobutyrate in concentrations above physiological levels, is very striking if one considers that all the glands, controls included, received enough valine to cover milk protein production (Hardwick and Linzell, 1960). It is well known that isobutyric acid is produced by the microbial attack of valine in the rumen and serves as a primer molecule for branched-chain 
fatty acid synthesis (Allison et al., 1961 ; Emmanuel, 1974). These acids are absorbed from the digestive tract and transported to the mammary gland by way of the blood stream (Keeney, Katz and Allison, 1962). Our results suggest that similar synthetic activities take place in the gland itself.

In preperfusion milk samples $\mathrm{d}$ and $\mathrm{O}$, derived from live animals after 20 and $24 \mathrm{~h}$ of fasting, respectively, we noted a decrease in the proportions of oddnumbered $\left(\mathrm{C}_{11: 0,}, \mathrm{C}_{13: 0}, \mathrm{C}_{15: 0}\right)$ and iso (iso $\mathrm{C}_{12: 0}$, iso $\mathrm{C}_{14: 0}$, iso $\mathrm{C}_{16: 0}$ ) acids, while the proportions of $C_{17: 0}$ and iso $C_{18: 0}$ rose. These results agree with a study of the effect of 48 hours of fasting on milk fatty acids in goats (Massart-Leën and Peeters, 1985). The decrease in the proportion of certain milk fatty acids during fasting is ascribed to a decrease of the main precursors in the blood and to a rise of the supply of other fatty acids which are derived from adipose tissue lipolysis (Linzell, 1967 ; Annison et al., 1968 ; Massart-Leën and Peeters, 1985). When, after fasting, the glands were perfused and in the presence of substantial amounts of valerate, isobutyrate (present experiments) or propionate (MassartLeën et al., 1983), odd-numbered $\left(C_{11: 0}, C_{13: 0}, C_{15: 0}\right)$ and iso (iso $C_{12: 0}$, iso $C_{14: 0}$, iso $C_{16: 0}$ ) acids rose again and returned to their previous levels, indicating that these substrates acted as precursors for the synthesis of the fatty acids concerned.

This conception may also explain variations in the proportions of major milk fatty acids. The concentrations of $C_{10: 0}, C_{12: 0}, C_{14: 0}$ and $C_{16: 0}$ decreased in the preperfusion milk samples, while $C_{18: 0}$ and $C_{18: 1}$ rose. After fasting, all the glands, controls included, were perfused in the presence of a complete substrate mixture containing adequate quantities of acetate and $\beta$-hydroxybutyrate. This resulted in a rise of the proportions of $C_{10: 0}, C_{12: 0}, C_{14: 0}$ and $C_{16: 0}$ and a decrease of $\mathrm{C}_{18: 0}$ and $\mathrm{C}_{18: 1}$. Our results obtained in the isolated gland are in line with the well known concept that milk fatty acids with a chain length of $\leqslant 16 \mathrm{C}$ are partially or completely synthesized from small molecules in the gland, whereas $C_{18: 0}$ and $C_{18: 1}$ are derived from the blood stream (Popjak et al., 1951).

The major fatty acids $\left(C_{10: 0}, C_{12: 0}, C_{14: 0}, C_{16: 0}\right)$ are highly correlated with each other while they are negatively correlated with $C_{18: 0}$ and $C_{18: 1}$. A highly positive correlation was expected between all the acids synthesized within the gland receiving adequate quantities of precursor. Table 2 shows the correlation between changes in the proportions of milk fatty acids from glands perfused in the presence of isobutyrate, acetate and $\beta$-hydroxybutyrate. This explains the high correlation between iso acids synthesized from isobutyrate and fatty acids with a chain length of $\leqslant 16 \mathrm{C}$ synthesized from acetate and $\beta$-hydroxybutyrate.

As the different substrates were added to the perfusate as sodium salts, they had to be converted to an active CoA form. A fatty acid synthetase preparation from lactating bovine mammary gland has the highest substrate specificity for $C_{2}$ and $\mathrm{C}_{3}$ compounds, while the activity of isobutyrate and isovalerate reached only $30 \%$ of the maximal specificity found for acetate and propionate (Cook et al., 1969). This is in line with the very small quantitative response in fatty acid synthesis observed in the present experiments in which excess valerate and isobutyrate were added : a maximum of $1 \%$ of the total fatty acids in the case of valerate 
and of $0.5 \%$ in the case of isobutyrate. Owing to analytical limitations, a possible effect of both precursors on the synthesis of milk short-chain $\left(\mathrm{C}_{4}-\mathrm{C}_{10}\right)$ fatty acids by non-malonyl-CoA pathways could not be investigated.

Recu en seotembre 1985. Accepté en février 1986.

Acknowledgements. - The authors are grateful to Mrs L. De Neve-Van Lancker, Mrs M. Onghena-Anaf, Mrs M. Buelens-Van Haute, Mr. G. Rasschaert and Mr. G. Grisolle for technical assistance.

Résumé. Effets du valérate et de l'isobutyrate sur la sécrétion des acides gras par la glande mammaire isolée et perfusée de la chèvre en lactation.

Nous avons perfusé durant 8 à $11 \mathrm{~h}$ les 2 glandes mammaires isolées de 6 chèvres en lactation en présence de sang oxygéné et hépariné. Le lait produit durant la perfusion a été collecté à chaque heure. Des quantités de glucose, d'acétate et d'acides aminés (valine comprise) étaient ajustées en fonction de la production laitière et ajoutées au perfusat.

L'une des deux glandes mammaires a été perfusée en présence d'un excès de valérate ou d'isobutyrate non marqués, tandis que la glande opposée servait de contrôle.

En comparant la composition du lait de ces glandes symétriques, nous avons observé une augmentation de la proportion des acides gras à nombre impair de carbone $\left(C_{11: 0}\right.$, $\mathrm{C}_{13: 0,}, \mathrm{C}_{15: 0}$ ) en présence de valérate. Le mécanisme de la synthèse des acides gras du lait à partir du valérate est discuté.

Dans l'expérience avec l'isobutyrate, une augmentation des acides iso $C_{12: 0}$, iso $_{14: 0}$ et iso $C_{16: 0}$ a été remarquée dans le lait après $5 \mathrm{~h}$ de perfusion. L'incorporation de la valine dans les acides ramifiés en position iso du lait pourrait donc se faire par l'intermédiaire de l'isobutyryl-CoA.

Lors des perfusions effectuées en présence d'un mélange de substrats complet, la proportion de certains acides gras majeurs $C_{10: 0}, C_{12: 0}, C_{14: 0}$ et $C_{16: 0}$ augmentait, tandis que la proportion de $C_{18: 0}$ et $C_{18: 1}$ diminuait. Nous estimons que la présence d'acétate et de $\beta$ hydroxybutyrate est à l'origine de ces phénomènes.

\section{References}

ALLISON M. J., BRYANT M. P., KEENEY M., KATZ I., 1961. The metabolic fate of isovalerate in Ruminococcus flavefaciens. J. Dairy Sci., 44, 1203.

ANNISON E. F., LINZELL J. L., WEST C. E., 1968. Mammary and whole animal metabolism of glucose and fatty acids in fasting lactating goats. J. Physiol., 197, 445-459.

COOK R. M., SU-CHIN C. LIU, QURAISHI S., 1969. Utilization of volatile fatty acids in ruminants. III. Comparison of mitochondrial acyl coenzyme A synthetase activity and substrate specificity in different tissues. Biochemistry, 8, 2966-2969.

DERRIG R. G., DAVIS C. L., CLARK J. H., 1973. Metabolism of arginine, ornithine and valine by bovine mammary gland. J. Dairy Sci., 56, 651.

EMMANUEL B., 1974. On the origin of rumen protozoan fatty acids. Biochim. biophys. Acta, 337, 404-413.

GERSON T., HAWKE J. C., SHORLAND F. B., 1960. The role of $n$-valeric acid in the synthesis of the higher saturated straight-chain acids containing an odd-number of carbon atoms in bovine milk fat. Biochem. J., 74, 366-368. 
HARDWICK D. C., LINZELL J. L., 1960. Some factors affecting milk secretion by the isolated perfused gland. J. Physiol., 154, 547-571.

HARDWICK D. C., LINZELL J. L., PRICE S. M., 1961. The effect of glucose and acetate on milk secretion by the perfused goat udder. Biochem. J., 80, 37-45.

HORNING M. G., MARTIN D. B., KARMEN A., VAGELOS P. R., 1961. Fatty acid synthesis in adipose tissue II. Enzymatic synthesis of branched-chain and odd-numbered fatty acids. $J$. biol. Chem., 236, 669-672.

JAMES A. T., PEETERS G., LAURYSSENS M., 1956. The metabolism of propionic acid. Biochem. J., 64, 726-730.

KEENEY M., KATZ J., ALLISON M. J., 1962. On the probable origin of some milk fat acids in rumen microbial lipids. J. am. Oil Chem. Soc., 39, 198-201.

LINZELL J. L., 1967. The effect of very frequent milking and of oxytocin on the yield and composition of milk in fed and fasted goats. J. Physiol., 190, 333-346.

MASSART-LEËN A. M., FLORESCU S., VERBEKE R., PEETERS G., 1970. Metabolism of $\left[1-{ }^{14} \mathrm{C}\right]$ palmitate and $\left[1-{ }^{14} \mathrm{C}\right]$ oleate by the perfused mammary gland of the sheep or goat. $J$. Dairy Res., 37, 373-387.

MASSART-LEËN A. M., DE POOTER H., DECLOEDT M., SCHAMP N., 1981. Composition and variability of the branched-chain fatty acid fraction in the milk of goats and cows. Lipids, 16 , 286-292.

MASSART-LEËN A. M., PEETERS G., 1985. Changes in fatty acid composition of milk fat of the goat after a 48 hour period of fasting. Reprod. Nutr. Dévelop., 25, 873-881.

MASSART-LEËN A. M., ROETS E., PEETERS G., VERBEKE R., 1983. Propionate for fatty acid synthesis by the mammary gland of the lactating goat $J$. Dairy Sci., 66, 1445-1454.

POPJAK G., FRENCH T. H., HUNTER G. D., MARTIN A. J. P., 1951. Mode of formation of milk fatty acids from acetate in the goat. Biochem. J., 48, 612-618.

RAMSEY H. A., DAVIS C. L., 1965 . Metabolism of n-butyrate by the adult goat. J. Dairy Sci., 48, 381-390.

RAO G. A., ABRAHAM S., 1975. Nonequilibration of acetyl units from fatty acids and glucose in mammary glands of lactating mice. J. Dairy Sci., 58, 1799-1802.

ROETS E., MASSART-LEËN A. M., VERBEKE R., PEETERS G., 1979. Metabolism of $\left[U-{ }^{14} \mathrm{C} ; 2-3-\right.$ ${ }^{3} \mathrm{H}$ ]-L-valine by the isolated perfused goat udder. J. Dairy Res., 46, 47-57.

ROETS E., VERBEKE R., MASSART-LEËN A. M., PEETERS G., 1974 . Metabolism of ${ }^{14} \mathrm{C}$ citrulline in the perfused sheep and goat udder. Biochem. J., 144, 435-446.

VAN SLYKE D. D., NEIL J. M., 1924. The determination of gases in blood and other solutions by vacuum extraction and manometric measurements. J. biol. Chem., 61, 523-573.

VERBEKE R., LAURYSSENS M., PEETERS G., 1959. Incorporation of DL- $\left[11^{14} \mathrm{C}\right]$ leucine and $\left[1-{ }^{14} \mathrm{C}\right]$ isovaleric acid into milk constituents by the perfused cow's udder. Biochem. J., 73, 24-29. 